Коне М. С., Корчан Л. М., кандидати ветеринарних наук

Полтавська державна аграрна академія

Забіяка О. О., лікар ветеринарної медицин

ТОВ «Біоцентр», м. Полтава

\title{
ЕФЕКТИВНІСТЬ ЛІКУВАННЯ ТА ПРОФІЛАКТИКИ ЧУМИ СОБАК В УМОВАХ ВЕТЕРИНАРНИХ КЛІНІК ТОВ «БІОЦЕНТР» М. ПОЛТАВА
}

\author{
Рецензент - кандидат ветеринарних наук К. В. Супруненко
}

\begin{abstract}
Вивчені породна та вікова чутливість, сезонність виникнення та динаміка прояву чуми собак в умовах ветеринарних клінік ТОВ «Біочентр» міста Полтава. Встановлено, що ензоотія чуми частіше проявлясться у весняно-літній період, більш схильні до зараження собаки породи німецька вівчарка. У випадку чуми собак нами розроблена та запропонована схема лікування кишкової форми, котра є значно ефективнішою за загальноприйняту базову методику. Обтрунтована важливість використання хіміотерапевтичних засобів на окремих стадіях розвитку інфекиійного процесу. Встановлено, щуо для профілактики чуми y собак найбільи ефективною виявилась вакцина «Нобівак DНPPI».
\end{abstract}

Ключові слова: чума, собаки, схема, лікування, профілактика.

Постановка проблеми. Чума собак - гостра контагіозна хвороба, що характеризується гарячкою, катаральним запаленням слизових оболонок органів дихання, травлення та сечовиділення, а також ураженням центральної нервової системи, очей та шкіри $[1,2,5]$.

Чума собак на сьогоднішній день $є$ одним 3 найпоширеніших інфекційних захворювань собак. Поряд зі значними матеріальними збитками, що заподіюються даним захворюванням, очевидним $\epsilon$ і моральний збиток, що наноситься власникам хворих тварин.

Загальні економічні збитки від чуми складаються із затрат від загибелі та вибракування тварин у службовому собаківництві та витрат на проведення профілактичних, протиепізоотичних і лікувальних заходів $[1,3,6]$.

Аналіз основних досліджень i публікацій, у яких започатковано розв'язання проблеми. Аналізуючи дані журналів реєстрації хворих тварин у ветеринарних клініках ТОВ «Біоцентр» за 2010-2014 роки, можна зробити висновок, що м. Полтава $€$ неблагополучним щодо чуми собак.

Діагностика захворювання в основному проводиться на підставі епізоотологічних даних, клінічних ознак і результатів лабораторних досліджень $[2,4,5]$.

У літературних джерелах зустрічається декілька схем лікування чуми собак, кожна з яких направлена на різні патогенетичні процеси.

Питання вакцинопрофілактики даного захворювання також залишається відкритим у зв'язку 3 великою кількістю вакцин, що випускаються біологіч-ною промисловістю.

Мета досліджень - вивчити епізоотологічні дані чуми собак в умовах ветеринарних клінік ТОВ «Біоцентр» міста Полтава.

Завдання - розробити найбільш ефективну схему лікування чуми собак та визначити ефективність різних вакцин, які використовуються у ветеринарних клініках міста Полтави.

Матеріали і методи досліджень. Дослідження проводилися в період 2010-2014 років на базі ветеринарних клінік ТОВ «Біоцентр» міста Полтава. У процесі вивчення чуми собак використовували епізоотологічний, клінічний і статистичний методи.

Під час проведення епізоотологічних досліджень, зокрема, з'ясовували: умови годівлі, утримання й контакти тварин до появи і в період захворювання, наявність інших інфекційних і неінфекційних хвороб у тварин, 3 якими відбулися контакти, тривалість і динаміку розвитку хвороби.

Для визначення ефективності різних схем лікування кишкової форми чуми в умовах ветеринарних клінік м. Полтава нами було сформовано три вікові групи по 5 тварин, хворих на кишкову форму чуми:

- перша група - віком від 2 до 6 місяців;

- друга група - віком від 6 місяців до 1 року;

- третя група - віком від 1 року і старше.

Лікування собак із застосуванням базової схеми грунтувалося на застосуванні дієти, антибіотикотерапії і регідратації організму.

Проводячи лікування собак із використанням дослідної схеми, основну увагу звертали на регід- 


\section{ВЕТЕРИНАРНА МЕДИЦИНА}

ратацію, стимуляцію імунітету, дотримання голодної дієти.

3 цією метою застосовували біологічні та фармакологічні речовини (колоїдні кристалоподібні речовини, імуностимулятори, антибіотики та ін.) згідно $з$ рекомендаціями і настановою по їх застосуванню.

Для поповнення втраченої рідини проводили крапельну інфузію сольових і декстранових розчинів.

Використовували розчин Рінгера, фізіологічний розчин натрію хлориду, реополіглюкін, 5\% розчин глюкози - внутрішньовенно щодня, три дні поспіль (за тяжкого перебігу чуми краплинну інфузію проводили двічі на добу).

3 метою усунення блювоти і регуляції моторики кишечника вводили «Церукал» у дозі 1,0-2,0 мл внутрішньовенно до припинення блювання.

Для підвищення опірності організму та поліпшення процесів обміну речовин застосовували «Катозал»у дозі 1,0-2,0 мл та «Гамавіт»у дозі 1,0-1,5 мл внутрішньовенно один раз на добу, щодня до одужання.

Крім того вводили $5 \%$ розчин аскорбінової кислоти в дозі 0,5-1,0 мл внутрішньовенно протягом 3-5 діб.

Внутрішньом'язево вводили полівалентну сироватку «Гіскан-5» проти чуми м’ясоїдних, парвовірусного, коронавірусного ентеритів та аденовірусних інфекцій собак (згідно з настановою по застосуванню) два дні поспіль.

Для попередження кров'яного проносу (або у разі його наявності) ми використовували «Етамзілат» у дозі 0,5-1,0 мл внутрішньом'язево до припинення кровотечі.

Протягом лікування хворим тваринам застосовували очисну клізму з відваром трави ромашки та кори дуба 3-4 рази на добу в перші три дні захворювання, паралельно призначали голодну дієту.

Визначення ефективності профілактики чуми собак проводили в умовах ветеринарних клінік ТОВ «Біоцентр» м. Полтава.

Для дослідження нами було використано три полівалентні вакцини від різних виробників:

1. «Вангард плюс» - проти чуми собак, аденовірозу типу 2, парагрипу, парвовірозу собак та лептоспірозу.

2. «Дурамун-8» - проти чуми, аденовірусної інфекції, коронавірусної інфекції, парагрипу, парвовірусного ентериту та лептоспірозу.

3. «Нобівак DHPPI» - проти чуми, парвовіру- сного ентериту, інфекційного гепатиту та парагрипу.

Для визначення ефективності даних вакцин нами було створено 3 групи тварин (собак) по 10 у кожній.

Перед уведенням вакцини тваринам був проведений клінічний огляд, термометрія, яка була в межах фізіологічної норми.

Вакцину вводили внутрішньом'язево згідно 3 настановою по застосуванню.

Результати дослідження. Для оцінки епізоотичної ситуації щодо чуми собак у м. Полтава ми аналізували дані ветеринарної звітності по захворюваності собак у ветеринарних клініках ТОВ «Біоцентр».

Нами відмічено, що захворювання частіше реєструється серед таких порід, як німецька вівчарка, ротвейлер, спанієль, а також безпорідні тварини.

Водночас до захворювання сприйнятливіші щенята у віці від 2 до 6 місяців. Значно менше сприйнятливі до хвороби такі породи, як американський стаффордширський терьєр, пітбуль, боксер, бультер'єр.

Аналізуючи записи в журналах реєстрації хворих тварин можна зробити висновок, що чума собак має виражену сезонність.

Максимальний підйом доводиться на веснянолітній і літньо-осінній періоди.

Очевидним $\epsilon$ те, що швидкому поширенню захворювання i широкому охопленню поголів'я собак чумою сприяє висока їх концентрація на одиницю площі міста, недостатня кількість вигульних майданчиків, i, як наслідок, контакт здорових собак із хворими та перехворілими, які контамінують грунт, рослини.

Крім того, одна $з$ причин поширення чуми собак, на наш погляд, є те, що далеко не всі господарі тварин проводять вакцинацію проти інфекційних хвороб, у тому числі і проти чуми м'ясоїдних.

Результати вивчення порівняльної ефективності різних схем лікування кишкової форми чуми собак на базі ветеринарних клінік ТОВ «Біоцентр» м. Полтава, представлені в таблиці 1.

Отримані результати таблиці 1 свідчать, що запропонована нами дослідна схема лікування чуми собак наведена в таблиці 2.

Як свідчать дані таблиці 2, найефективнішим методом профілактичної вакцинації проти чуми собак є використання «Нобівак DHPPI». Iз 10 тварин жодна не захворіла. 
ВЕТЕРИНАРНА МЕДИЦИНА

1. Терапевтична ефективність різних схем лікування кишкової форми чуми собак

\begin{tabular}{|c|c|c|c|c|c|c|c|c|c|c|}
\hline \multirow{4}{*}{ 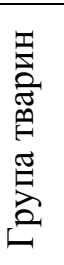 } & \multirow{4}{*}{ 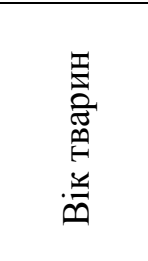 } & \multirow{4}{*}{ 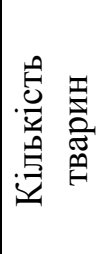 } & \multicolumn{8}{|c|}{ Терапевтична схема } \\
\hline & & & \multicolumn{4}{|c|}{ Базова } & \multicolumn{4}{|c|}{ Дослідна } \\
\hline & & & \multicolumn{2}{|c|}{ загинуло } & \multicolumn{2}{|c|}{ одужало } & \multicolumn{2}{|c|}{ загинуло } & \multicolumn{2}{|c|}{ одужало } \\
\hline & & & тварин & $\%$ & тварин & $\%$ & тварин & $\%$ & тварин & $\%$ \\
\hline 1 & 2-6 мic. & 5 & 5 & 100,0 & - & - & 2 & 40,0 & 3 & 60,0 \\
\hline 2 & $\begin{array}{c}6 \text { міс.- } \\
1 \text { рік }\end{array}$ & 5 & 3 & 60,0 & 2 & 40,0 & 1 & 20,0 & 4 & 80,0 \\
\hline 3 & $\begin{array}{l}1 \text { рік і } \\
\text { старше }\end{array}$ & 5 & 1 & 20,0 & 4 & 80,0 & - & - & 5 & 100,0 \\
\hline
\end{tabular}

2. Порівняльна ефективність різних вакцин у разі профілактики чуми собак

\begin{tabular}{|c|c|c|c|c|c|c|}
\hline \multirow{2}{*}{ Група тварин } & \multirow{2}{*}{$\begin{array}{c}\text { Кількість } \\
\text { тварин }\end{array}$} & \multirow{2}{*}{ Вакцини } & \multicolumn{2}{|c|}{ Не захворіло } & \multicolumn{2}{|c|}{ Захворіло } \\
\cline { 4 - 7 } & & $\begin{array}{c}\text { Аболютне } \\
\text { число }\end{array}$ & $\%$ & $\begin{array}{c}\text { Абсолютне } \\
\text { число }\end{array}$ & $\%$ \\
\hline 1 & 10 & $\begin{array}{c}\text { «Вангард } \\
\text { плюс» }\end{array}$ & 8 & 80,0 & 2 & 20,0 \\
\hline 2 & 10 & «Дурамун-8» & 9 & 90,0 & 1 & 10,0 \\
\hline 3 & 10 & $\begin{array}{c}\text { «Нобівак } \\
\text { DНРРІ» }\end{array}$ & 10 & 100,0 & - & - \\
\hline
\end{tabular}

\section{Висновки:}

1. Чума собак частіше проявляється у веснянолітній період року та реєструється у собак різного віку, але більш схильні до захворювання тварини віком від двох до шести місяців.

2. Розроблена нами схема лікування кишкової

\section{БІБЛІОГРАФІЯ}

1. Бессарабов Б. Ф. Інфекційні хвороби тварин / Б. Ф. Бессарабов, Є. С. Воронін. - М. : Колос, 2007. $-671 \mathrm{c}$.

2. Галкіна T. С. Эпизоотическая ситуация по чуме плотоядных у собак в условиях города Владимира / Т. С. Галкина, Л. А. Глобенко, Н. В. Мороз // Вет. патология. - Владимир, 2006. - №4. C.147-149.

3. Головаха В. I. Лікування кишкової форми чуми м'ясоїдних у собак / В. І. Головаха, Л. С. Коротенко, О.А. Дикий // Тези II міжнар. конф. «Проблеми ветеринарного обслуговування дрібних домашніх тварин». - К., 1997. - С. 11-12.

4. Гловаха B .I. Застосування регідраційної те- форми чуми собак $є$ більш ефективною в порівнянні з базовою методикою, водночас збереженість тварин значно вища.

3. Для профілактики чуми у собак, найбільш ефективною виявилась вакцина виробництва Голандії «Нобівак DHPPI».

рапії при чумі та парвовірусному ентериті собак / В. І. Головаха, В. С. Корнієнко : зб. матеріалів IV міжнар. наук.-практ. конф. «Проблеми ветеринарного обслуговування дрібних домашніх тварин». - Біла Церква, 1999. - С. 60-62.

5. Лукьяновский В. А. Болезни собак / В. А. Лукьяновский, Ю. И. Филипов, Н. А. Максимов. - М. : Росагропромиздат, 1998. - 434 с.

6. Руденко П. А. Эффективность применения катозала при лечении вирозов у собак в условиях города Луганска / П. А. Руденко, А. А. Руденко // Збірник наукових праць ЛНАУ. Серія «Ветеринарні науки». - Луганськ, 2005. - С. 249-253. 